\title{
Becoming Neolithic. The Mesolithic-Neolithic transition and its impact on the flint and stone industry at Swifterbant (the Netherlands)
}

\author{
Izabel Devriendt \\ Groningen Institute of Archaeology, University of Groningen, the Netherlands \\ i.i.j.a.l.m.devriendt@rug.nl
}

\begin{abstract}
The Mesolithic-Neolithic transition is traditionally defined by a change in subsistence strategy. New ideas are picked up, and animal husbandry and cereal cultivation are adopted as hunter-gatherers evolve. This article examines whether these economic changes stand on their own or lead to changes in other aspects of life. The study will illustrate the innovations in the flint and stone industry (including ornaments) during the Swifterbant period (5000-3400 BC). These include changing debitage techniques and preferences, and the abandonment of the micro-burin technique, but also the introduction of grinding stones, polished axes and amber ornaments. The significance of these new features will be investigated as characteristics of the changing identity of the Swifterbant Culture.
\end{abstract}

IZVLEČEK - Mezolitsko-neolitska tranzicija je običajno definirana s pomočjo spremenjenih subsistenčnih strategij. Predstavljeni so novi razmisleki o razvoju živinorejskega gospodarstva in kultiviranju žitaric pri lovcih in nabiralcih. V članku ugotavljamo, ali so spremembe v pleogospodarskih strategijah povzročile spremembe tudi $v$ drugih segmentih življenja. Predstavljamo spremembe in inovacije v produkciji (in ornamentiki) kamenih izdelkov v obdobju Swifterbant (5000-3400 BC). Te so vezane na spremembe $v$ odbitkovnih tehnikah in opustitvi mikrovbadalne tehnike ter vpeljavi žrmelj, glajenih sekir in okrasa iz jantarja. Pomen novih predmetov vidimo v spreminjanju identitete kulture Swifterbant.

KEY WORDS - Neolithic; flint; stone; bipolar knapping technique; ornaments

\section{Introduction}

The Swifterbant Culture encompasses the Late Mesolithic and the Early Neolithic in the main part of the Netherlands, the north of Belgium and the northwest of Germany. This cultural period runs from 5000 to $3400 \mathrm{BC}$, between the Linear Band Ceramic Culture (LBK) and the Funnel Beaker Culture. In the Netherlands, the LBK is limited to the small loess area in the south of the country, while in the other parts the Late Mesolithic still continues. Over time these Late Mesolithic hunter-gatherers become early farming communities by adopting Neolithic trade marks. The first of these novelties is pottery, produced in typical Swifterbant tradition from around $5000 \mathrm{BC}$ onwards.
Later on, animal husbandry was introduced. The earliest evidence for cattle and sheep/goat is now dated at $4600 \mathrm{BC}$, while pig is introduced around $4200 \mathrm{BC}$ (Raemaekers 2003.742; Raemaekers 2005.261, 277). For years, the presence of grinding stones, charred grains and chaff remains (Cappers and Raemaekers in prep.) were strong indicators of cereal cultivation, but the exact nature, magnitude and location remained indistinct. Grain was presumably cultivated in the vicinity of the sites, but more accurate evidence was lacking. Recent discoveries at site $S 4$ proved beyond a doubt the introduction of cereal cultivation at some time in the middle phase of the 
Swifterbant Culture (4300-4000 BC). Although the lasting importance of wild food resources cannot be underestimated, the introduction of animal husbandry and cereal cultivation indicate that the Swifterbant Culture developed into a Neolithic tradition by adopting certain traits from its Neolithic neighbours.

The transition from the Mesolithic to the Neolithic is traditionally defined by a change in subsistence strategy. Hunter-gatherers change their way of life and become farming communities. New ideas are picked up as animal husbandry and cereal cultivation are adopted. One can imagine that this economic change does not stand on its own. These new ideas will lead to new discoveries and, finally, will bring about a cascade of changes in all aspects of life. But old routines and traditions are not lost or discarded when new traits are introduced. What new aspects trickle through into the flint industry? How will the existing stone tool production alter when new items are introduced? Which tool types, production techniques and raw materials are adopted, and which artefact types are maintained within the existing tool-kit?

Although many aspects of everyday life change in this transitional phase, this article will focus only on the innovations, alterations and transformations this change brings about in the flint and stone industry, including stone ornaments, during the Swifterbant period. First, a general introduction will highlight the different phases within the Swifterbant Culture. Then the New Swifterbant Project, in which this research is set, is presented. The flint and stone industry are then discussed and special attention is given to stone ornaments. In order to give a clear insight into the evolution of the lithic industries, and their corresponding sites, they will be presented chronologically. The late Swifterbant phase will not be described in detail, as the little information that is available will be given in the general introduction. Finally, all the new features will be considered as characteristics of the changing identity of the Swifterbant Culture.

The Swifterbant Culture is defined by its distinctive pottery and, therefore, the division of the period into three phases is based on the stylistic elements of this pottery (e.g. Raemaekers 1999; 2005). The major sites from the early phase (5000-4600 BC) are Hoge Vaart, Polderweg and De Bruin - all thoroughly investigated find locations (Hogestijn and Peeters 2001; Louwe Kooijmans 2001a; 2001b). Besides pottery, the material culture of this period is characterised by a Late Mesolithic flint industry and by stone artefacts such as cooking stones, tempering material, hammer stones, and anvils. The organic material culture includes T-shaped antler axes and other antler tools, bone awls, bows, fish-weirs, fyke nets, peddles and canoes. Subsistence is still based on hunting, gathering, fishing and fowling, while animal husbandry will be introduced at the transitional stage from the early to the middle phase, around $4600 \mathrm{BC}$.

The type-site of Swifterbant (Fig. 1) is an example of the middle phase (4600-3900 BC). In this paper it will be compared to well known sites from the early phase in order to better comprehend the evolution of the Swifterbant Culture as it traverses the boundary from the Late Mesolithic to the Neolithic. During this middle phase, the Swifterbant Culture experiences a dichotomy into a northern and southern cultural sphere. The Swifterbant type-site, located in the northern cultural sphere, is found in an area characterised by Late Pleistocene river dunes (with Mesolithic and Neolithic occupation) and a Holocene freshwater tidal creek system, with Neolithic levee sites inhabitable between $4300-4000 \mathrm{BC}$. During this period, at least three of these levee sites were inhabited, namely S2, S3 and S4. It is important to state that most of the other sites from this middle phase, such as Bergschenhoek, Brandwijk and Hazendonk, yielded only very small amounts of flint artefacts, so it is hard to compare these Swifterbant type-sites within their own timeline.

The late phase (3900-3400 BC) is poorly documented because only one reliable site (Schokkerhaven) has been found thus far. During this phase the dichotomy deepens, as the southern group evolved into the Hazendonk 3 group, while its northern counterpart developed into the Late Swifterbant Culture. For the northern group, the trend started in the middle phase seems to continue. The flint industry is still based on flake production which possibly becomes increasingly important. The arrowhead type is the same as at the Swifterbant type-sites (trapezes) and thus presumably remains the same as in the middle phase. Polished axes also still occur. Then again, the isolation of this site makes this conclusion provisional (Hogestijn 1990; Raemaekers 20032004). Another site from this phase (P14), with a very long inhabitation sequence and poor stratigraphical evidence, is characterised by transverse arrowheads, trapezes, triangular points and leaf-shaped points (Wilhelm 1996). However, the significance and reliability of this find cannot be attested. 
Since the discovery of the type-site near the village of Swifterbant in the 1960's, research has periodically made new discoveries, whether related to flint technology, raw material usage or agricultural innovations. Still, several aspects of the social and economic organisation remained obscure. Therefore new research in different areas of expertise has been conducted since the New Swifterbant Project started in 2004, with new fieldwork and research into several topics. The focal points of the project are the relations between human occupation and landscape development, the suitability of the area for cereal cultivation, and the use of the landscape outside the settled areas (see Raemaekers et al. 2005). One of the sub-research fields re-evaluates the flint and stone material from the type-site of Swifterbant, in order to investigate, for example, debitage techniques, or determine typological differences and gain an insight into raw material usage and imported items. This research is in progress, so this paper needs to be regarded as a status quo of the new insights gained as of March, 2008. A full and definite report will be published in 2009 (i.e. Devriendt in prep.a).

\section{The flint industry}

The early Swifterbant phase (5000-4600 BC)

Sites of relevance for this phase are Hoge Vaart, Polderweg and De Bruin. The first site, Hoge Vaart, has been studied in detail and reported fully (Peeters, Schreurs and Verneau 2001). In this early stage of the Swifterbant Culture, strong Late Mesolithic affinities are still present within the flint industry. The debitage sequence is based on the production of regular blades from platform cores. The rolled nodules were tested and prepared at the procurement sites and transported to the settlement site, where they were exploited until abandonment. Direct, hard percussion was applied in the first stages of the core preparation, while blade production was performed by indirect percussion. The regular blades have parallel edges and ridges, and are usually between 3$6 \mathrm{~cm}$ long. They were selected for the production of predominantly arrowheads, namely trapezes. Other arrowhead types found less frequently are different kinds of microlith. The use of the micro-burin technique to divide the blade into two or more fragments is typical. More irregular shaped blades were cho-

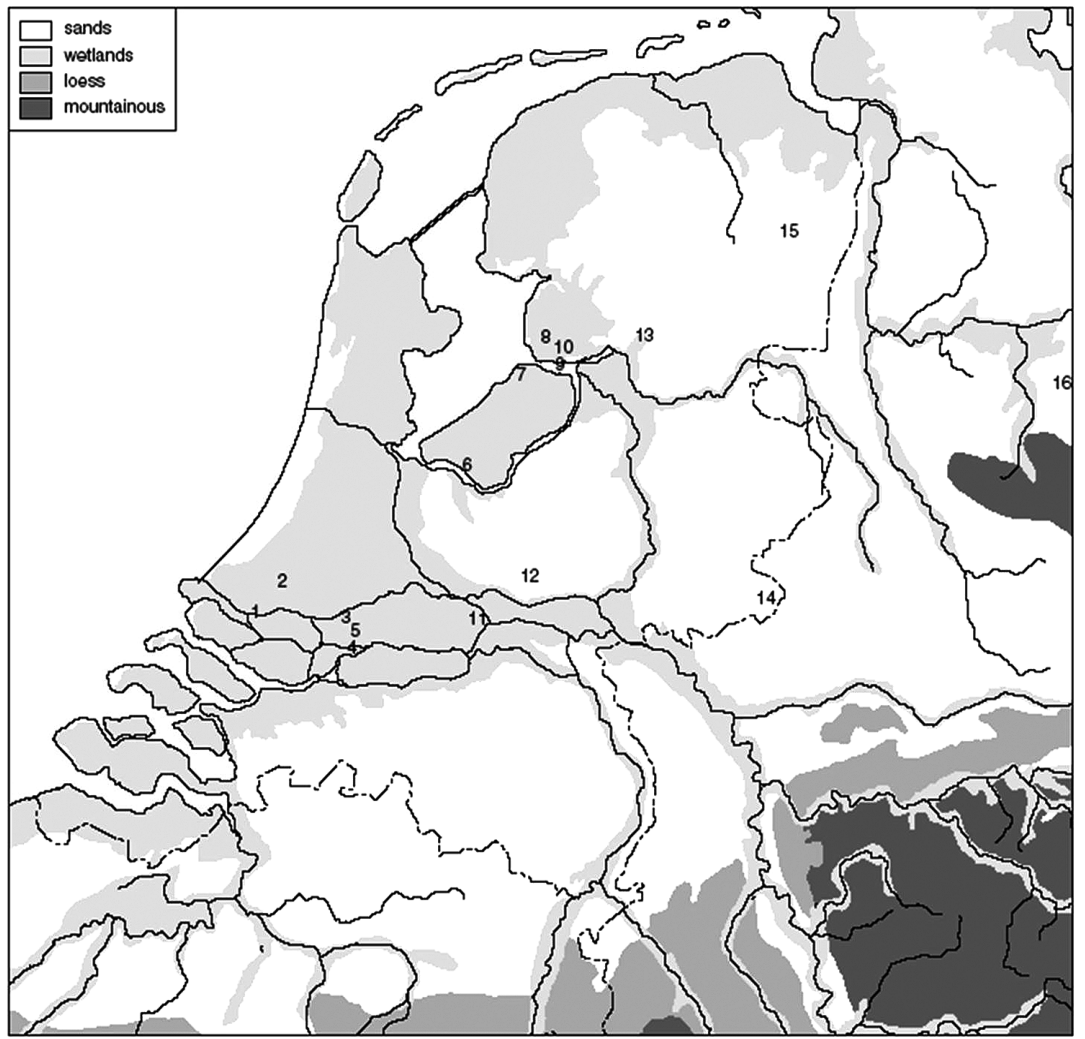

Fig. 1. The sites (known in 1999) belonging to the Swifterbant Culture: 1 - Schiedam; 2 - Bergschenhoek; 3 - Brandwijk; 4 - Polderweg; 5 - Hazendonk; 6 - Hoge Vaart; 7 - Swifterbant cluster; 8 -J112; 9 - P14; 10 Schokkerhaven; 11 - Zoelen-Buren; 12 - Ede-Rietkamp; 13 - De GasteMeppel; 14 - Winterswijk; 15 - Bronneger; 16 - Hûde (taken from Raemaekers 1999.Fig. 3.1). The Swifterbant type-site is no. 7. sen to be used unmodified as knives. Only in some cases were they lightly retouched (backed blades). Thicker examples and accidentally produced flakes were predominantly used as blanks for scrapers. Of course, other tools such as retouched pieces, borers and burins, also occur, being made from both blades and flakes. Use-wear analysis shows that fresh hide working was the main activity, while tools for bone and antler processing were almost absent. There is also some indication of ritual flint deposition (Peeters, Schreurs and Verneau 2001).

The flint industry of the other two sites, Polderweg and De Bruin, is characterised by flakes, largely because of the very small size of the used nodules, which do not allow the production of blades (Van Gijn, Beugnier and Lammers-Keijsers 2001; Van Gijn, Lammers and Houkes 2001). The arrow- 
head types which occur are trapezes and transverse arrowheads, combined with a large variety of microliths. The strong Mesolithic character of this industry is illustrated. It must be noted that all three sites mentioned here also have Late Mesolithic inhabitation phases. For most or all microliths it is furthermore unclear how long into the Mesolithic they were used as arrowhead types.

These last two sites give a dual impression of the flint industry of the Swifterbant Culture in this phase; both blade and flake production predominate. Therefore, we might cautiously presume that both the Hoge Vaart site, like the two other sites, Polderweg and De Bruin, are good representatives of the early phase of the Swifterbant Culture.

\section{The middle Swifterbant phase (4600-3900 BC)} As mentioned above, the middle phase is characterised by a dichotomy into a northern and southern cultural sphere. The Swifterbant type-sites S2, S3 and S4, dated 4300-4000 BC, are distinctive of the northern group. These settlements are located on levees in a fresh water creek system consisting of a main gully and several tributaries ${ }^{1}$.

During the middle phase, lithic production focused on flakes from platform cores. At S2 the flakes comprise $23 \%$ of the material, while blades only take up $14 \%$. The same tendency is visible in S3, with $38 \%$ of flakes and $12 \%$ of blades, while at $\$ 4$ these numbers are respectively $18 \%$ and $6 \%$. Cores are worked on from one or two platforms and only seldom from three or more platforms.

Although one of the Swifterbant sites of the southern cultural sphere, Brandwijk, shows more new arrowhead types, such as leaf shaped and drop shaped points (Raemaekers 1999.58), on the Swifterbant type-sites only one new type is seen. This transverse arrowhead reminds one of a trapezoid arrowhead, but it differs in dimensions. Instead of being long rather than wide, it is now wide rather than long. The trapezes, however, remain the dominant arrowhead type. We must bear in mind that this typological difference was perhaps not seen in the same way by the Swifterbant people. The only difference is, after all, in the shifting dimensions. With 20000 artefacts analysed, which is almost $65 \%$ of the mate- rial, and since no micro-burins have been found, it is presumed that trapezes and transverse arrowheads were no longer produced with the micro-burin technique, but by breaking blades 2 .

The analysis of the debitage material shows that the bulk of the material was produced at the site. As a case in point, the material from site S3 is used, as it is the most numerous. When the measurements of the non-fractured flakes and blades are compared to those of the preparation and rejuvenation pieces, it can be seen that the larger blades and some larger flakes are not covered (Fig. 2). It is perceivable that these would be decortication pieces. For the flakes, some of the larger pieces are indeed decortication flakes (Fig. 3). This implies that all or most flakes were produced at the site. For the blades, this picture is different. The group of blades larger than $5 \mathrm{~cm}$ that were not covered by the preparation or rejuvenation pieces are not decortication blades either. This implies that these large blades are not produced at the site, but imported as ready-made products from somewhere else 3 .

The importation of blades or any other item does not always involve movement over long distances. The raw material used hints at this. All the large blades mentioned above are of the regular type, with parallel edges and ridges, produced from platform cores. The raw material used is the same as that of the smaller blades and flakes found on all sites and is of local origin. The most likely sources are two boulder clay outcrops at $12 \mathrm{~km}$ and $15 \mathrm{~km}$ distance of the Swifterbant type-site. This indicates that the large blades were possibly not imported over a long distance and that the raw material used for these blades presumably came from the same procurement sites as all the other flint artefacts. But the procurement site does not need to be the production site. Moreover, boulder clay deposits are found over a larger area in the north of the Netherlands, so imports from further located sources cannot be ruled out.

As these regular blades show great similarities to those from the early phase, they can be seen as the continuation of this tradition, but innovations within the flint industry also occur. The presence of a second debitage method, the bipolar technique, also known as the hammer and anvil technique, has been

\footnotetext{
1 At two other levee sites, S41 and S51, habitation is attested by archaeological evidence while levee sites S31 and S42-S43 are only mapped through auger surveys.

2 of course, it cannot be ruled out that they were all made somewhere else, although this is highly unlikely.

3 However, it might also entail that all large preparation and rejuvenation pieces, as well as decortication blades, were taken from the site, although that is improbable.
} 


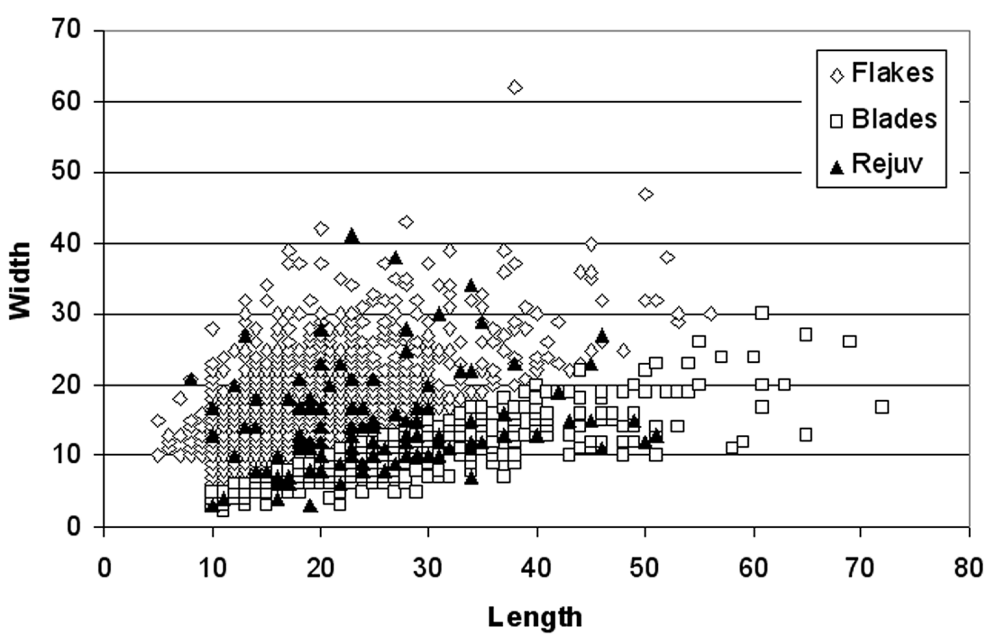

Fig. 2. Preparation and rejuvenation pieces set against complete flakes and blades (site S3, Swifterbant).

detected. It is especially the systematic employed of this technique that is significant. The core is no longer handheld or placed on the thigh, but is set on a stone anvil and smashed with a hammer stone from above. Bipolar cores and splintered pieces or pièces esquilées have been defined in the past. The description and the function of the technique and the endproducts have been a topic of debate since their first definition.

Bipolar pieces are mostly functionally defined as tools, like wedges (pièce esquilée) (Hayden 1980) or burins (MacDonald 1968), or are sometimes defined as cores (Guyodo and Marchand 2005; Ballin 1999; White 1968). The use of the bipolar technique has also been interpreted as the solution to a raw material shortage (Callahan 1987; Deckers 1982; Kamminga 1978), the opening of rounded nodules (Van Gijn and Niekus 2001), or as the work of apprentices or children, thus skill related (Stapert 2007; Sternke and Sörensen 2007). It is even seen as the work of women, as it is sometimes considered a "low prestige" technique (Flenniken 1979), while in other parts of the world bipolar flakes are used predominantly by men (Kosambi 1967). Of course, one cannot rule out that two or more functions may coexist. This paper will only provide an insight into the material from the Swifterbant type-sites and will give a site-specific interpretation. Although tradition and social organisation pro- bably have an influence on the bipolar matter, these topics will not be discussed here. They will be brought up, along with gender related issues and other, more detailed information, in a separate paper which focuses solely on the bipolar technique (Devriendt in prep.b).

Regular bipolar cores, irregular bipolar pieces and splintered pieces have been found on the Swifterbant sites S2, S3, and S4. This distinction is based mostly on morphology and technology, and partially on presumed function. Typical of all the pieces is the lack of a striking platform and the lenticular shape in side-view created by two opposing striking ridges or striking points. They are produced from small nodules of local flint with a length up to $5 \mathrm{~cm}$. The high degree of uniformity of the regular bipolar cores and the standardisation of dimensions of the splintered pieces is remarkable.

Several trains of thoughts are being pursued at the moment. The first presented itself during the study of the bipolar pieces. In this theory, I considered the three types as different steps in a chaîne opératoire, with the splintered pieces as an end result. This would be a functional interpretation with a tool, the splintered pieces, as goals for production. In order to verify this assumption, use-wear analysis was preformed 4 on $4 \%$ of the bipolar pieces $(n=18)$ and on $11 \%$ of the splintered pieces $(n=10)$. Surprisingly, only two artefacts showed traces of use. One bi-

4 This research was done by Karsten Wentink, Lithic Laboratory, Faculty of Archaeology, Leiden University. 
polar core was used as a burin, and one splintered piece was used on plant material. Most unexpected was that the majority of the splintered pieces, or all the other bipolar pieces for that matter, had not been used at all. With only 4 or $11 \%$ of the bipolar pieces analysed, it is possible that the sample size was too small. However, if they had been used systematically as a wedge, the analysis would have picked it up. If the functional interpretation of bipolar pieces as wedges is off the table, two other possible functional explanations remain. Firstly, the bipolar pieces are used as tools but so rarely or in such a way that it leaves no visible use-wear traces. Secondly, they are cores.

This leads to the second train of thought: that the bipolar technique is a response to a raw material shortage (Callahan 1987; Deckers 1982; Kamminga 1978). Two related hypotheses present themselves. The bipolar technique is used for opening small nodules without wasting flint on extensive platform preparation, or even in the initial stages of core reduction for testing nodules and for cortex removal. Callahan (1987) works along the same lines when he writes that the bipolar technique is a part of the chaîne opératoire which starts with the freehand debitage of platform cores, and when these become smaller, the platform core is placed on an anvil. It is only in the final stage that, according to him, bipolar percussion is applied.

A third train of thought has been gaining ground recently. Some scholars (Stapert personal communication November 2007) and recent experiments have shown that young children steady the core on the floor for a better grip (Sternke \& Sørensen 2007; Sternke personal communication March 2008), possibly as compensation for lack of motor skills. Whether it is the result of mimicry by children, or just children playing, or whether it is a structural part within skill transmission to apprentices, is still under investigation.

With Occam's Razor5 in mind a fourth train of thought forces itself upon us. The bipolar technique is used alongside the platform technique as an opportunistic way of exploiting all the flint available. Thus they can be considered as two separate methods of working flint. Of course, none of these lines of thought need stand on their own. A combination of different aspects and factors is therefore more than likely. Furthermore, as research continues, it is not even sure the division into three types still holds.
The function, meaning and interpretation of the bipolar technique might still be obscure, but the fact that the technique is being introduced as a systematically applied debitage technique in this period is not. It can be seen as an important innovation, as it is not the portent of declining debitage techniques: it is evidence of an opportunistic and highly adaptive and flexible way of knapping flint.

\section{The stone industry}

\section{The early Swifterbant phase}

As with flint production, strong Late Mesolithic affinities are still present in the stone industry. On the site of Hoge Vaart, the bulk of the stone material comprised small granite and quartz fragments, whereas only a limited amount of larger, stone artefacts was found (Peeters 2001). The small stone fragments were used as temper for the on-site production of pottery. Others were presumably the result of cobbles being used as cooking stones. This high fragmentation rate prohibits a good insight into, and definition of larger stone tools on this site. Even so, a hammer stone, an arrow shaft polisher, a chopping tool, several flakes and other stone tools have been defined. The study of the flint blades and scrapers made it apparent that anvils must also have been present at the site, not only for retouching tools, but also possibly for the production of temper. Unfortunately, no such tools or tool fragments have been identified, presumably due to fragmentation (Peeters personal communication April 2008).

On the sites at Polderweg and De Bruin (Van Gijn, Louwe Kooijmans and Zandstra 2001; Van Gijn and Houkes 2001), where roughly the same variety of tools was found as on the Hoge Vaart site, anvils were even used for the opening of rounded nodules. Although this use of hammer stone and anvil would fall under the definition of bipolar technique, some remarks should be made. The bipolar technique was already used during the Palaeolithic and the Mesolithic, but it is its frequency that becomes different in the Neolithic. Possibly starting in the early phase of the Swifterbant Culture, but definitely in the middle phase, it is introduced as a systematically employed technique and no longer applied sporadically.

\section{The middle Swifterbant phase}

The stone industry of the middle phase of the Swifterbant Culture is characterised by tools like grinding stones, hammer stones, anvils, and polished axes and adzes. The distinction between this phase and

5 "All things being equal, the simplest solution tends to be the right one." 
the previous one is overwhelming. New tools and particularly their abundance stand out.

One of the most important, if not the most important, tools of this period is the grinding stone. With the rise of grain as a new food source, a new tool type meeting the specific requirements of this specific plant was needed. And although grinding stones are not a new invention, they are introduced into the Swifterbant Culture during this middle phase. It is apparent that the Swifterbant grinding stones lack any form modelling or stylistic elements. The only rule that seems to apply is ease of use and work comfort. This stands in sharp contrast with the Linear Band Ceramic Culture or the Beaker Cultures, where bowl or saddle shaped grinding stones are common (Beuker 1990). A grinding tool consists of two components that need to be used together, a handheld stone (handstone or mano) and a lying stone (netherstone or metate) (Adams 2002). For handstones, natural rounded cobbles were selected that lie comfortably in the palm of the hand. The netherstones need to remain firmly on the ground, so boulders were chosen with either two opposing flat surfaces or with a flat surface opposing a protruding area which could be dug into the ground.

A second interesting aspect here is the fragmentation rate. When all stone tools are compared, it stands out that five times as many grinding stones 6 are broken as hammer stones or anvils. This might, of course, point towards taphonomy, but the frequency rather indicates special treatment of grinding stones. Could it be possible that this tool type was intentionally destroyed when people, by example, left the settlement? Several other explanations may be valid. Some of the small grinding stones may be used as cooking stones. When a grinding surface has become too smooth to perform, it is roughened by pounding on it with a hammer stone or even perhaps with another, small grinding stone. Sometimes a grinding stone is used as a multifunctional tool and is employed as an anvil or hammer stone. And when a grinding stone can no longer be exploited, it can always be used as tempering material if the raw material is suitable, all of which can lead to fragmentation.

Although anvils were present during the early phase, their use must have been increasingly important and systematic in the middle phase for their number rises significantly. Anvils become standard issue in the tool-kit. They are no longer solely used for the retouching of tools or for the sporadic opening of rounded nodules, but for a wide variety of tasks. Impact traces differ greatly in depth and extensiveness, suggesting diverse applications. Centred impact traces sometimes even create small hollows, while some anvils have the appearance of mortars as the hollow deepens.

All these tools were produced out of local raw material (see section on flint), except for several polished adzes. These were imported from the south of the Netherlands, or even from Germany or Poland, the area of the Rössen Culture; a contemporary, fully developed Neolithic culture in the Central-European loess areas which can be seen as the successor of the LBK. The imported Rössen adzes are characterised by a straight perforation oriented parallel to the cutting edge of the adze. The raw material used for these tools is of German and/or Polish origin. Remarkable are two adzes found at site $S 3$, which have a deviant shape. The perforation is bi-conical or hour-glass shaped and is oriented obliquely to the cutting edge of the adze. The reason for this oblique orientation is not yet known, but the difference in perforation is significant. The use of pecking or a solid drill, which results in an hour-glass shaped perforation is considered a Mesolithic characteristic $(G e$ röllkeulen and Spitzhauen), while the use of a hollow drill resulting in a straight perforation is typical of fully developed Neolithic cultures (Schuhleistenkeilen and Breitkeilen). Furthermore, the raw material used for these deviant adzes is of local origin. This makes the interpretation as local copies plausible.

\section{The amber ornaments}

This special find category that appeals to everybody's imagination forms only a small part of the stone industry at the Swifterbant sites. Lumps of this fossil resin were perforated and worn as pendants or beads, sometimes individually, sometimes strung together with or without pendants made from other raw materials. Only $17 \%(n=4)$ of the inhumations at the Swifterbant cemeteries showed evidence of ornaments (Devriendt in prep.c; Raemaekers et. al. in prep; Meiklejohn and Constandse-Westerman 1978). These were not only made from amber, but also from stone pebbles and animal teeth. It appears that for the Swifterbant-type sites the ornaments fa-

6 Due to the fragmentation it is not always possible to define the pieces as handstone or netherstone, therefore, the more neutral term 'grinding stone' is chosen. 
bricated from stone pebbles were produced on-site (there are many semi-finished products) while the amber beads and pendants were clearly imported. The pendants made of animal teeth were presumably imported as well (Devriendt in prep.c).

The most remarkable finds were discovered in the grave of a man on site $\mathrm{S} 2$. He was buried with five amber ornaments strung across his forehead, along with one sandstone pendant, located near his right ear, and a perforated fragment of a boar's tusk on his chest. Three of these five amber ornaments are the biggest found in all the Swifterbant burials. Equally compelling is the grave of a woman on the same site. She was buried with seven beads around her neck, one bead near her pelvis and, probably, three beads around her head, thus possibly eleven amber ornaments in total. Another special find, is the small amber pendant found in the grave of a child on S4. Although this is the only child buried with ornaments, it shows that men and women as well as children were, in some circumstances, buried with ornaments. This example also illustrates the different number, composition and even size of the ornaments given to different people. The man was buried with seven artefacts made of three different raw materials. The woman even had eleven artefacts but only made of one raw material. The child was buried with just one gift. Whether this is an indication of status, sex, age, personal wealth, or some other form of social differentiation is still under investigation. We must also bear in mind that gifts made of organic material have long perished. And although a fair number of graves is known $(\mathrm{n}=37)$ (Raemaekers et al. in prep) the limited number of Swifterbant sites with graveyards, three to be precise, also impedes this research.

The funerary practises, i.e. the inhumation of people on their back in an extended position (e.g. Alberthsen and Brinch Petersen 1970), as well as the presence of animal teeth pendants, are still very Mesolithic minded. Even the presence of amber lumps have been attested at archaeological sites in the Netherlands from the Palaeolithic onwards (Waterbolk and Waterbolk 1991). The introduction of amber ornaments in graves during the Swifterbant period is, however, of great importance. It is the first time that amber lumps have been transformed into beads and pendants. In this pioneering phase, amber lumps are only perforated and not altered in any other way. In later phases, when they are being produced more systematically, for example during the Single Grave Culture, amber lumps are not only perforated, but also cut, scraped, and ground (Piena and Drenth 2001; Bulten 2001). It is also during the middle Swifterbant phase that amber beads and pendants are recovered from graves for the first time.

\section{The analysis of the new features}

It has long been common practice that subsistence is the main feature in defining the difference between the Mesolithic and Neolithic (e.g. Zvelebil 1998). This would imply that the introduction of animal husbandry and cereal cultivation would have been the most important innovation of that time. It is most likely that the Swifterbant people did not see it in that way.

The introduction of pottery at the beginning of their cultural period, or is it the other way around, is probably of more significance. This could imply that the Swifterbant people had more use for an innovation like a decent pot for storage or cooking than they had for animal husbandry. Of course, it is easy to take the functional explanation as the prime one. Cultural restrains, social taboos or even technical complexity make the adoption of new aspects by a culture an unequal fight. One might think that the adoption of successful cereal cultivation is harder to accomplish than the herding and feeding of animals. Whether this is the reason animal husbandry was adopted first is difficult to fathom. It is also possible that the Rössen people were more protective of their agricultural technology and thus more reluctant to share this information with others.

Regardless of how, when and why cereal cultivation was adopted, the introduction of grain apparently implied the introduction of grinding stones. Perhaps the properties of emmer wheat and naked barley make it necessary to crush and grind the grains before they are cooked. Therefore, the one could not go without the other. We might assume that this led to the special standing of grinding stones, as it was a material symbol of the new agricultural technique.

The imported adzes must also have been a very special item for the Swifterbant people, presumably with high significance (Louwe Kooijmans 2005; Verhart 2000). The exoticism of the raw material, the time invested during production, and the technical ingenuity, must have appealed to the Swifterbant people's imagination. Therefore, grinding stones and polished adzes might have been Neolithic icons or symbols of the new way of life. 
Thus, the Swifterbant Culture might be characterised by their interest in Neolithic traits, and defined by all sorts of innovations, adoptions and introductions, regardless of the importance we give them. Still, the lithic industry, the burial practises and the perseverance of collecting wild food, prove that they remained loyal to their Mesolithic traditions and did not change their ways overnight. We must also bear in mind that the Neolithisation process was more likely to be one of trial and error than a straightforward success story.

\section{Conclusion}

That the Swifterbant Culture evolved from a Late Mesolithic tradition towards an almost fully Neolithic one can be illustrated by comparing the sites of the Swifterbant early phase with the type-sites from the middle phase. The lithic industry of sites S2, S3, and $\mathrm{S} 4$ is being analysed systematically to gain insight into how this culture was affected by the Neolithisation process.

The flint industry of the Swifterbant Culture started out as Late Mesolithic. Over time, it developed into a more Neolithic tradition by adopting new tools and debitage techniques. This began with a change from a blade to a more flake orientated industry and by abandoning the micro-burin technique for making arrowheads. More precisely, for the Swifterbant typesites it has been attested that on the one hand, small flakes and blades, produced with the platform technique from local flint were created on the site itself. On the other hand, large blades also produced with the platform technique and from local flint were brought to the site. So, regardless of where they were manufactured, flakes and blades were produced from local raw material. Furthermore, the bipolar technique was introduced as a systematically applied debitage technique. A new set of arrowheads was being used, ranging from trapezes and transverse arrowheads to leaf and drop shaped points, depending on the sites.

The stone industry depended on Mesolithic types, such as hammer stones and anvils, but was at the same time radically changed by the introduction of grinding stones. The high fragmentation rate of these artefacts leads one to suspect that they were treated in a special way. Amber beads and pendants were produced for the first time, and only a small number of the Swifterbant people were buried with them. Finally, imported polished adzes brought influences with them from the south of the country, where a true Neolithic culture resided. By making their first polished adzes, the Swifterbant people took into their own hands the final step to becoming fully Neolithic.

\section{$\therefore$}

\section{REFERENCES}

ADAMS J. L. 2002. Ground Stone Analysis: A Technological Approach. University of Utah Press, Salt Lake City.

ALBERTHSEN S. E., BRINCH PETERSEN E. 1976. Excavations of a Mesolithic Cemetery at Vedbaek, Denmark. Acta Archaeologica 47: 1-26.

BALLIN T. B. 1999. Bipolar Cores in Southern Norway. Classification, Chronology and Geography. Lithics 20: 1322.

BEUKER J. 1990. Werken met steen. Drenths Museum. Assen.

BULTEN E. 2001. Het barnsteen van de laat-neolithische nederzetting 'Mienakker': Een onderzoek naar de bewerking van barnsteen in een nederzetting van de Enkelgrafcultuur. In R. M. van Heeringen and E. M. Theunissen (eds.), Kwaliteitsbepalend onderzoek ten behoeve van duurzaam behoud van neolithische terreinen in West-
Friesland en de Kop van Noord-Holland. Deel 3: Archeologische onderzoeksverslagen. Rijksdienst voor het Oudheidkundig Bodemonderzoek, Amersfoort: 471-483.

CALLAHAN E. 1987. An evaluation of the lithic technology in Middle Sweden during the Mesolithic and Neolithic. Societas Archaeologica Upsaliensis. Uppsala (= Aun 8).

CAPPERS R. T. J., RAEMAEKERS D. C. M. in prep. Cereal cultivation at Swifterbant? About being a Neolithic wetland farmer in the western part of the North European Plain. Current Anthropology.

DECKERS P. H. 1982. Preliminary notes on the Neolithic flint material from Swifterbant (Swifterbant Contribution 13). Helinium 22: 33-39.

DEVRIENDT I. in prep.a. The stone and flint artefacts from Swifterbant (provisional title). Ph. Dissertation. University of Groningen. Groningen. 
in prep.b. Bipolar pieces: a question of function, raw material availability or skill. A case-study of the Neolithic sites at Swifterbant (The Netherlands). Lithic Technology.

in prep.c. "Diamonds are a girl's best friend". Neolithische kralen en hangers uit Swifterbant. Westerheem.

FLENNIKEN J. J. 1979. Replicative systems analysis of the lithic artifacts from Hoko River archaeological site. Unpublished Ph.D. dissertation. Department of Anthropology, Washington State University. Washington.

GUYODO J.-N., MARCHAND G. 2005. La percussion bipolaire sur enclume dans l'Ouest de la France de la fin du Paléolithique au Chalcolithique: une lecture économique et sociale. Bulletin de la Société Préhistorique Française 102 (3): 539-549.

HAYDEN B. 1980. Confusion in the Bipolar World: Bashed Pebbles and Splintered Pieces. Lithic Technology 9 (1): 2-7.

HOGESTIJN J. W. 1990. From Swifterbant to TRB in the IJssel-Vecht Basin - Some Suggestions. In D. Jankowska (ed.), Die Trichterbecherkultur. Teil I. Neue Forschngen und Hypothesen. Poznan: 163-180.

HOGESTIJN J. W. H., PEETERS J. H. M. 2001. De mesolithische en vroeg-neolithische vindplaats Hoge Vaart-A27 (Flevoland). Rijksdienst voor het Oudheidkundig Bodemonderzoek, Amersfoort (= ROB Rapportage Archeologische Monumentenzorg 79).

KAMMINGA J. J. 1978. Journey into the microcosms: a functional analysis of certain classes of prehistoric Australian stone tools. Unpublished Ph.D. dissertation. Department of Anthropology, University of Sydney. Sidney.

KOSAMBI D. D. 1967. Living prehistory in India. Scientific American 216 (Feb.): 105-114.

LOUWE KOOIJMANS L. P. 2001a. Hardinxveld-Giessendam Polderweg. Een mesolithisch jachtkamp in het riviergebied (5500-5000 v. Chr.). Rijksdienst voor het Oudheidkundig Bodemonderzoek, Amersfoort (= Rapportage Archeologische Monumentenzorg 83).

2001b. Hardinxveld-De Bruin: een kampplaats uit het Laat-Mesolithicum en het begin van de Swifterbant-cultuur (5500-4450 v. Chr.). Rijksdienst voor het Oudheidkundig Bodemonderzoek, Amersfoort (= Rapportage Archeologische Monumentenzorg 88).

2005. Ook de jagers worden boer. Vroeg-neolithicum B en midden-neolithicum A. In L. P. Louwe Kooijmans, P. W. van den Broeke, H. Fokkens and A. van Gijn (eds.), Nederland in de Prehistorie. Bakker, Amsterdam: 249-271.

MACDONALD G. 1968. Debert: a Paleo-Indian site in central Nova Scotia. Anthropology Papers, National Museum of Canada 16.

MEIKLEJOHN C., CONSTANDSE-WESTERMAN T. S. 1978. The human skeletal material from Swifterbant, Earlier Neolithic of the Northern Netherlands: I. Inventory and demography. Final Reports on Swifterbant I. Palaeohistoria 20: 39-89.

PEETERS J. H. M. 2001. Deel 19. Natuursteen: karakterisering en gebruik. In J. W. H. Hogestijn and J. H. M. Peeters (eds.), De mesolithische en vroeg-neolithische vindplaats Hoge Vaart-A27 (Flevoland). Rijksdienst voor het Oudheidkundig Bodemonderzoek, Amersfoort (= ROB Rapportage Archeologische Monumentenzorg 79).

PEETERS J. H. M., SCHREURS J., VERNEAU S. M. J. P. 2001. Deel 18. Vuursteen: typologie, technologische organisatie en gebruik. In J. W. H. Hogestijn and J. H. M. Peeters (eds.), De mesolithische en vroeg-neolithische vindplaats Hoge Vaart-A27 (Flevoland). Rijksdienst voor het Oudheidkundig Bodemonderzoek, Amersfoort (= ROB Rapportage Archeologische Monumentenzorg 79).

PIENA H., DRENTH E. 2001. Doorboorde sieraden van de laat-neolithsche site Aartswoud, gem. Opmeer. In R. M. van Heeringen and E. M. Theunissen (eds.), Kwaliteitsbepalend onderzoek ten behoeve van duurzaam behoud van neolithische terreinen in West-Friesland en de Kop van Noord-Holland. Deel 3: Archeologische onderzoeksverslagen. Rijksdienst voor het Oudheidkundig Bodemonderzoek, Amersfoort: 433-469.

RAEMAEKERS D. C. M. 1999. The Articulation of a 'New Neolithic'. The meaning of the Swifterbant Culture for the process of neolithisation in the western part of the North European Plain (4900-3400 BC). Faculty of Archaeology. University of Leiden. Leiden. (=Archaeological Studies Leiden University 3)

2003. Cutting a long story short? The process of neolithization in the Dutch delta re-examined. Antiquity 77: 740-748.

2003-2004. An outline of Late Swifterbant pottery in the Noordoostpolder (provincie of Flevoland, the Netherlands) and the chronological development of the pottery of the Swifterbant culture. Palaeohistoria 45/ 46: 11-36.

2005. Het vroeg- en midden-neolithicum in Noord-, Midden- en West-Nederland. In J. Deeben, E. Drenth, M.F. van Oorsouw and L. Verhart (eds.), De steentijd 
van Nederland. Stichting Archeologie, Zutphen. (= Archeologie 11/12): 261-282.

RAEMAEKERS D. C. M., DEVRIENDT I., CAPPERS R. T. J., PRUMMEL W. 2005. Het Nieuwe Swifterbant Project. Nieuw onderzoek aan de mesolithische en neolithische vindplaatsen nabij Swifterbant (provincie Flevoland, Nederland). Notae Praehistoricae 25: 119-127.

RAEMAEKERS D. C. M., MOLTHOF H. M., SMITS E. in prep. The textbook 'dealing with death' from the Neolithic Swifterbant culture (5000-3400 BC), The Netherlands.

STAPERT D. 2007. Neanderthal children and their flints. PalArch's Journal of Archaeology of Northwest Europe 1 (2): 16-38.

STERNKE F., SÖRENSEN M. 2007. The Identification of Children's Flintknapping Products in Mesolithic Scandinavia. In S. McCartan, R. Schulting, G. Warren and P. C. Woodman, (eds.), Mesolithic horizons. Papers presented at the Seventh International Conference on the Mesolithic in Europe, Belfast 2005. Oxbow Books, Oxford.

VAN GIJN A. L., BEUGNIER V., LAMMERS-KEIJSERS Y. 2001. Vuursteen. In L. P. Louwe Kooijmans (ed.), HardinxveldGiessendam Polderweg. Een mesolithisch jachtkamp in het riviergebied (5500-5000 v. Chr.). Rijksdienst voor het Oudheidkundig Bodemonderzoek, Amersfoort (= Rapportage Archeologische Monumentenzorg 83): 119-161.

VAN GIJN A. L., LAMMERS Y., HOUKES R. 2001. Vuursteen. In L. P. Louwe Kooijmans (ed.), Hardinxveld-De Bruin: een kampplaats uit het Laat-Mesolithicum en het begin van de Swifterbant-cultuur (5500-4450 v. Chr.). Rijksdienst voor het Oudheidkundig Bodemonderzoek, Amersfoort (= Rapportage Archeologische Monumentenzorg 88): 153-191.

VAN GIJN A. L., LOUWE KOOIJMANS L. P., ZANDSTRA J. G. 2001. Natuursteen. In L. P. Louwe Kooijmans (ed.), Har-
dinxveld-Giessendam Polderweg. Een mesolithisch jachtkamp in het riviergebied (5500-5000 v. Chr.). Rijksdienst voor het Oudheidkundig Bodemonderzoek, Amersfoort (= Rapportage Archeologische Monumentenzorg 83): $163-179$.

VAN GIJN A. L., HOUKES R. 2001. In L. P. Louwe Kooijmans (ed.), Hardinxveld-De Bruin: een kampplaats uit het Laat-Mesolithicum en het begin van de Swifterbantcultuur (5500-4450 v. Chr.). Rijksdienst voor het Oudheidkundig Bodemonderzoek, Amersfoort (= Rapportage Archeologische Monumentenzorg 88): 193-207.

VAN GIJN A., NIEKUS M. 2001. Bronze Age Settlement Flint from the Netherlands: the Cinderella of Lithic Research. In W. H. Metz, B. L. Van Beek and H. Steegstra (eds.), Patina. Essays Presented to Jay Butler on the Occasion of his 80th Birthday. Groningen: 305-320.

VERHART L. B. M. 2000. Times fade away: the neolithization of the Southern Netherlands in an anthropological and geographical perspective. Faculty of Archaeology, Leiden University. Leiden.

WATERBOLK H. J., WATERBOLK H. T. 1991. Amber on the Coast of the Netherlands. In H. Thoen, J. Bourgeois, F. Vermeulen, Ph. Crombé and K. Verlaeckt (eds.), Liber Amicorum Jaques A. E. Nenquin. (= Studia Archaeologica). Seminarie voor Archeologie, Gent: 201-209.

WHITE J. P. 1968. Fabricators, outils écaillés, or scalar cores? Mankind 6: 658-666.

WILHELM L. C. G. 1996. De vuurstenen pijlpunten van P14. Internal report Amsterdam University. Amsterdam.

ZVELEBIL M. 1998. What's in a Name: the Mesolithic, the Neolithic, and Social Change at the Mesolithic-Neolithic Transition. In M. Edmonds and C. Richards (eds.), Understanding the Neolithic of north-western Europe. Gruithne Press, Glasgow: 1-36. 
